\title{
Biofertilizer effect and dead coverage on green dwarf coconut (Cocos nucifera L.)
}

\begin{abstract}
The objective was to evaluate the vegetative growth of dwarf coconut as a function of biofertilizer in the presence and absence of mulch. The experiment was conducted at ChácaraMãeD’Água in the municipality of Belém do Brejo do Cruz, PB from 2014 to 2015. The experimental design was in randomized blocks, with five replications in a factorial arrangement of $6 \times 2$ and 12 treatments. The treatments were related to six dosages of biofertilizer $\left(0,500,1000,1500,2000\right.$ and $\left.2500 \mathrm{~mL} \mathrm{plant}^{-1}\right)$ in the presence and absence of soil cover. The interaction provided a significant effect on plant height, leaf area and leaf area of the plant. Probably the cover favored a barrier in the soil avoiding loss of water by evaporation and high temperatures, providing ideal conditions for the action of the microorganisms present in the biofertilizer. The interaction of the factors promotes development of green dwarf coconut, making a viable alternative to family farming.
\end{abstract}

Keywords: agroecology, coconut, organic fertilizer
Volume 8 Issue 5 - 2018

\author{
Francisco Hélio Alves de Andrade,' José \\ Avelino de Queiroga Neto, ${ }^{2}$ Ubiratan \\ Matias de Queiroga Junior, ${ }^{2}$ Ériton Eriberto \\ Martins Dantas, ${ }^{2}$ Wiliam Fernandes Batista, ${ }^{2}$ \\ Raimundo Andrade, ${ }^{2}$ Maria Isabela Batista \\ Clemente ${ }^{3}$ \\ 'Universidade Federal de Lavras, Pós-Graduação em Fisiologia \\ Vegetal, Brazil \\ ${ }^{2}$ Universidade Estadual da Paraíba, Licenciatura Plena em \\ Ciências Agrárias, Brazil \\ ${ }^{3}$ Universidade Estadual do Rio Grande do Norte, Curso de \\ Gestão Ambiental, Brazil
}

Correspondence: Francisco HélioAlves de Andrade, Universidade Federal de Lavras, Pós-Graduação em, Fisiologia Vegetal, Lavras, MG, Brazil, Email helioalvesuepb@gmail.com

Received: March 09, 2018 | Published: September 21, 2018

\section{Introduction}

The green dwarf coconut (Cocos nucifera L.) is one of the most known crops on the planet, in which its production occurs constantly, in addition to being a product of several utilities such as: coconut water; Cocada; pulp; candy; substrates etc. Coconut trees present continuous growth, which implies the removal of large amounts of nutrients, which need to be replenished through the application of fertilizers. ${ }^{1}$ The nutritional status of coconut trees influences their vegetative growth, in addition to determining, in great part, the volume and the quality of the production. ${ }^{2}$ New technologies are being studied to meet the nutritional requirements of the green dwarf coconut (Cocos nucifera L.), while promoting sustainability by obtaining products free of chemical inputs. In Brazil, the advent of organic agriculture began in the 1990s, with liquid biofertilizers being used to control pests and diseases in plant growth, development and nutrition. ${ }^{3}$

Organic production aims at sustainability and a balance of soil and other natural resources. ${ }^{4}$ The bovine biofertilizer is one of the most used in ecologically based agriculture, being easily accessible to the farmer. Bacteria, such as Bacillus and Pseudomonas, are organisms that are studied for the biological control of various plant diseases. ${ }^{5}$ Besides contributing to the improvement of soil chemical and physical conditions, it can minimize the effect of salinity on irrigation water. Application of the biofertilizers provided adequate calcium nutrition and only then did the element contribute to increase the wall thickness of the pepper since the nutrient increases the calcium pectate content important for tissue formation. ${ }^{6}$ The exploitation of fruit trees with biofertilizer, such as banana nanicão (Musa spp.) By Santos et al. ${ }^{7}$ (Passiflora edulis f. flavicarpa Deg.) by Mesquita et al. ${ }^{8}$ and Freire et al. ${ }^{9}$ Green dwarf coconut (Cocos nucifera L.) by Campos et al. ${ }^{10}$ has been growing, aiming at a production free of chemical residues from conventional agriculture.

The use of soil mulching is a widely recommended practice, particularly in semi-arid regions, contributing to improved crop performance and increased soil moisture retention. ${ }^{11}$ Organic matter is an excellent soil conditioner, improving its physical, chemical and biological characteristics, favoring water retention, aggregation, porosity, cation exchange capacity, soil fertility and microbiota. ${ }^{12}$ The same authors report that coverages such as, for example, tifton grass are more efficient than napier in soil temperature control. Organic production becomes an alternative free of chemical inputs, bringing benefit to human health. The objective was to evaluate the vegetative growth of green dwarf coconut (Cocos nucifera L.) as a function of the application of biofertilizer in the presence and absence of mulch.

\section{Material and methods}

The research was carried out under field conditions from 2014 to 2015 , in the town of Chácara Mãe D'Água in the municipality of Belém do Brejo do Cruz, $\mathrm{PB}$, following the coordinates of $6^{\circ}$ $11^{\prime} 20$ 'S, $37^{\circ} 32^{\prime} 9^{\prime} \mathrm{W}$. The climate of the region is of the BSWh' type, ie warm and dry of the steppe type according to the KOPPEN classification, with monthly average temperature above $18^{\circ} \mathrm{C}$, during all year. The average annual temperature of this municipality is 26,90 $\mathrm{C}$ and an average annual evaporation of $1707,0 \mathrm{~mm}$. The experiment was planned in a factorial arrangement of $6 \times 2$, totaling 12 treatments. The treatments were related to six doses of enriched biofertilizer $\left(0,500,1000,1500,2000\right.$ and $\left.2.5 \mathrm{~mL}_{\text {plant- }}{ }^{1}\right)$, in the presence and absence of cover $(\mathrm{C} 1=$ presence and $\mathrm{C} 0=$ Absence $)$ in vegetative growth of coconut green dwarf (Cocos nucifera L.) produced under field conditions in the municipality of Belém do Brejo do Cruz, PB. The biofertilizer was applied at intervals of 60 days, from the third month after planting (DAP). Prior to application, the biofertilizer was subjected to screen filtration to separate the solid material.

Before the start of the experiment, soil samples were collected for subsequent analyzes, in the $0-50 \mathrm{~cm}$ layer, and were homogenized and transformed into composite samples, which were analyzed in 
the Laboratory of Soils and Nutrition of Plants (LSNP), Embrapa Algodão . It was analyzed with the following attributes: $\mathrm{pH}$ in $\mathrm{H} 2 \mathrm{O}=5,0 ; \mathrm{Ca}=20 \mathrm{mmol} . \mathrm{dm}_{-}{ }^{3} ; \mathrm{Mg}=8.5 \mathrm{mmol} . \mathrm{dm}-3 ; \mathrm{Na}=1.5 \mathrm{mmol}$. $\mathrm{dm}^{-3} ; \mathrm{K}=2.8 \mathrm{mmol} . \mathrm{dm}^{-3} ; \mathrm{S}=32.8 \mathrm{mmol} . \mathrm{dm}-3 ; \mathrm{H}+\mathrm{Al}=28.9 \mathrm{mmol}$. $\mathrm{dm}^{-3} ; \mathrm{T}=61.7 \% ; \mathrm{V}=53 \% ; \mathrm{Al}=7.5 \mathrm{mmol} . \mathrm{dm}^{-3} ; \mathrm{P}=1.6 \mathrm{mg} . \mathrm{dm}-3$ and M.O $=10.7 \mathrm{~g} . \mathrm{kg}^{-}{ }^{1}$. The biofertilizer based on bovine manure was produced anaerobically in a plastic container, with a capacity of 240 liters, were kept hermetically sealed, containing a hose attached to a clear plastic bottle with water (water seal) for removal of the methane gas produced inside the vessel by the fermentation of anaerobic bacteria. The material used to produce this organic fertilizer consisted of $70 \mathrm{~kg}$ of green manure from lactating cows and $120 \mathrm{~L}$ of water, $4 \mathrm{~kg}$ of rock meal (MB-4), $5 \mathrm{~kg}$ of legumes (beans), $3 \mathrm{~kg}$ of ash of wood plus $5 \mathrm{~L}$ of milk and $5 \mathrm{~kg}$ of sugar for acceleration of the metabolism of the bacteria during 35 (thirty five) days, on average. ${ }^{12}$ The chemical composition of the biofertilizer was analyzed from the dry matter, applied in green dwarf coconut (Cocos nucifera L.) plants in the interval of 30 days. The biofertilizer was analyzed in the Soil Fertility Laboratory (LFS) of the Federal Rural University of Pernambuco (UFRP), Recife, PE. Chemical characteristics: $\mathrm{pH}$ in $\mathrm{H} 2 \mathrm{O}=5,25$; EC dS. $\mathrm{m}-1=7.1 ; \mathrm{N}=0.8 \% ; \mathrm{P}=403.4 \mathrm{mg} . \mathrm{dm}^{-3} ; \mathrm{K}=1.78 \mathrm{cmol}^{-\mathrm{L}-{ }^{-}} ; \mathrm{Ca}=6.0$ cmolc. $\mathrm{L}^{-1}$. The mulch was collected at Fazenda Mãe D'Água in the municipality of Belém do Brejo do Cruz, PB. In which it spent 5 days for drying in the sun and soon after, was introduced in the experiment covering a radius of 2 meters. The culture used to cover Capimandrequicé (Leersia hexandra). After one year the following variables were collected: Plant height (AP); stem diameter (DC); number of leaves per plant (NF/P) unit leaf area (AFU); leaf area of the plant (AFP) and leaf area index (LAI).

The plant height was achieved by measuring with granulated metric tape in centimeters from the plant neck to the beginning of the leaves. The diameter of the stem was through measuring with a tape measure granulated in centimeters in the lap of the plant a distance of 5 centimeter of the ground. The number of leaves per plant and number of leaflets per leaf and per plant were determined by counting them, then the leaf area and plant length were calculated with leaf length $x$ width $\mathrm{x}$ adjustment factor measurements. However, the total leaf area was calculated by the number of leavesxleaf area of the plant.The leaf area index (LAI, m2) is the functional relationship between the leaf area and the area of the land occupied by the crop. Considering that agricultural yield is expressed by the amount of material harvested per unit area, it is valid to express leaf area on the same basis of yield ${ }^{14}$

$$
\mathrm{IAF}=\mathrm{AFP} / \mathrm{AOC}
$$

On what,

$$
\text { AFP (plant leaf area) and AOC (area occupied by the crop). }
$$

The design was in randomized blocks. The data were analyzed and interpreted from the analysis of variance (F-test) and later regression was used by the SISVAR $^{\circledR}$ software (System of analysis of variance, version 5.3$){ }^{15}$

\section{Results and discussion}

The statistical analysis revealed the effect of the biofertilizer doses on the unit leaf area, leaf area of the plant and number of leaflets per green dwarf coconut (Cocos nucifera L.) plant. On the other hand, soil cover presented statistical significance for plant height, foliar area and leaf area of the plant. The interaction promoted statistical significance in plant height, unit leaf area and leaf area of the plant (Table 1). It is observed that plant height was increased, with biofertilizer doses increasing in the absence of coverage, to the optimum point of $1300 \mathrm{~mL} /$ plant, corresponding to $23.63 \mathrm{~cm}$, in which there was an increase of
$14.5 \%$ in relation to witness. However, the presence of cover did not promote effect at plant height when submitted to increasing doses of biofertilizer (Figure 1A). It is probable that the increases observed up to the optimal doses of biofertilizer in the mentioned cycles have been due to the improvement of the physical, chemical and biological characteristics of the soil over time. ${ }^{16}$ The highest plant height at the estimated dose of $1300 \mathrm{~mL} /$ plant is associated with the nutritional balance for the crop, between the soil and biofertilizer. According to Malavolta et al. ${ }^{17}$ \& Dantas et al. ${ }^{18}$ the decrease can be explained by the accumulation of microorganism from the increasing doses of biofertilizer from the estimated dose, with competition for nutrients. Since the biofertilizer offers the nutrients in the form assimilable by the plants, and after a few days did not have enough fertilizer for both. Alves et al. ${ }^{19}$ observed that the number of fruits per banana plank increased with increasing doses of biofertilizer, to the optimum point of $1530 \mathrm{~mL}$ plant- ${ }^{-}$, with a reduction from the optimal dose.

Table I Result of the analysis of variance in vegetative growth of green dwarf coconut (Cocos nucifera L.) as a function of doses of bio fertilizer, mulch and

\begin{tabular}{|c|c|c|c|c|c|}
\hline \multirow[t]{2}{*}{$\begin{array}{l}\text { Source of } \\
\text { variation }\end{array}$} & \multirow[t]{2}{*}{ DF } & \multicolumn{4}{|l|}{$\begin{array}{l}\text { Square } \\
\text { medium }\end{array}$} \\
\hline & & PH & DC & NL & SLA \\
\hline $\begin{array}{l}\text { Biofertilizer } \\
\text { (B) }\end{array}$ & 5 & $2.665^{\mathrm{ns}}$ & $1.750^{\mathrm{ns}}$ & $0.070^{\text {ns }}$ & $1009.919^{* *}$ \\
\hline D. Linear & I & $2.443^{\mathrm{ns}}$ & $0.068^{\mathrm{ns}}$ & $0.035^{\mathrm{ns}}$ & $1350.024^{* *}$ \\
\hline D. Quadratic & I & $3.484^{\mathrm{ns}}$ & $0.990^{\mathrm{ns}}$ & $0.096^{\mathrm{ns}}$ & $0.953 \mathrm{~ns}$ \\
\hline Mulch (C) & I & $21.961 * *$ & $0.000 \mathrm{I}^{\mathrm{ns}}$ & $0.016^{\mathrm{ns}}$ & $386.79 \mid * *$ \\
\hline $\begin{array}{l}\text { Interaction } \\
\mathrm{B} \times \mathrm{C}\end{array}$ & 5 & $5.774 *$ & $0.545^{\mathrm{ns}}$ & $0.096^{\mathrm{ns}}$ & $80.338 * *$ \\
\hline Block & 4 & 5.356 & 0.237 & 0.233 & 0.841 \\
\hline Residue & 44 & 2.084 & 1.268 & 0.296 & 0.207 \\
\hline $\mathrm{CV}$ & & 6.3 & 9.7 & 10 & 4.2 \\
\hline
\end{tabular}
interaction of factors. Belém do Brejo do Cruz, PB, 2014/I5

Source of GL Square

\begin{tabular}{|c|c|c|c|c|c|}
\hline & & TLA & LAI & NL L-' & NL P-I \\
\hline $\begin{array}{l}\text { Biofertilizer } \\
\text { (B) }\end{array}$ & 5 & $5396.382 * *$ & $0.015^{\mathrm{ns}}$ & $1.016^{\mathrm{ns}}$ & $83.390 * *$ \\
\hline D. Linear & I & $5762.099 * *$ & $0.007^{\mathrm{ns}}$ & $\left.1.20\right|^{\mathrm{ns}}$ & $375.955 * *$ \\
\hline D. Quadratic & 1 & $9531.036 * *$ & $0.062 *$ & $0.576^{\mathrm{ns}}$ & $1.542^{\mathrm{ns}}$ \\
\hline Mulch (C) & I & $553.219 * *$ & $0.006^{\mathrm{ns}}$ & $12.150 *$ & $0.416^{\mathrm{ns}}$ \\
\hline $\begin{array}{l}\text { Interaction } \\
\mathrm{BxC}\end{array}$ & 5 & $2660.566 * *$ & $0.005^{\mathrm{ns}}$ & $2.350^{\mathrm{ns}}$ & $3.096^{\mathrm{ns}}$ \\
\hline Block & 4 & II.443 & 0.014 & 1.566 & 9.858 \\
\hline Residue & 44 & 22.611 & 0.015 & 1.93 & 3.331 \\
\hline CV & & 1.38 & 13.89 & 4.38 & I \\
\hline
\end{tabular}

medium

** and * meanings at $0.01,0.05$ and ns significant levels of probability by Tukey's test, respectively. Plant height (PH); diameter of the colon (DC); number of leaves (NL); single leaf area (SLA); total leaf area (TLA); leaf area index (LAl); number of leaflets per leaf $\left(\mathrm{NLL}^{-1}\right)$; number of leaflets per plant $\left(N \mathrm{NL}^{-1}\right)$; degree of freedom (DF) and coefficient of variation (CV). 

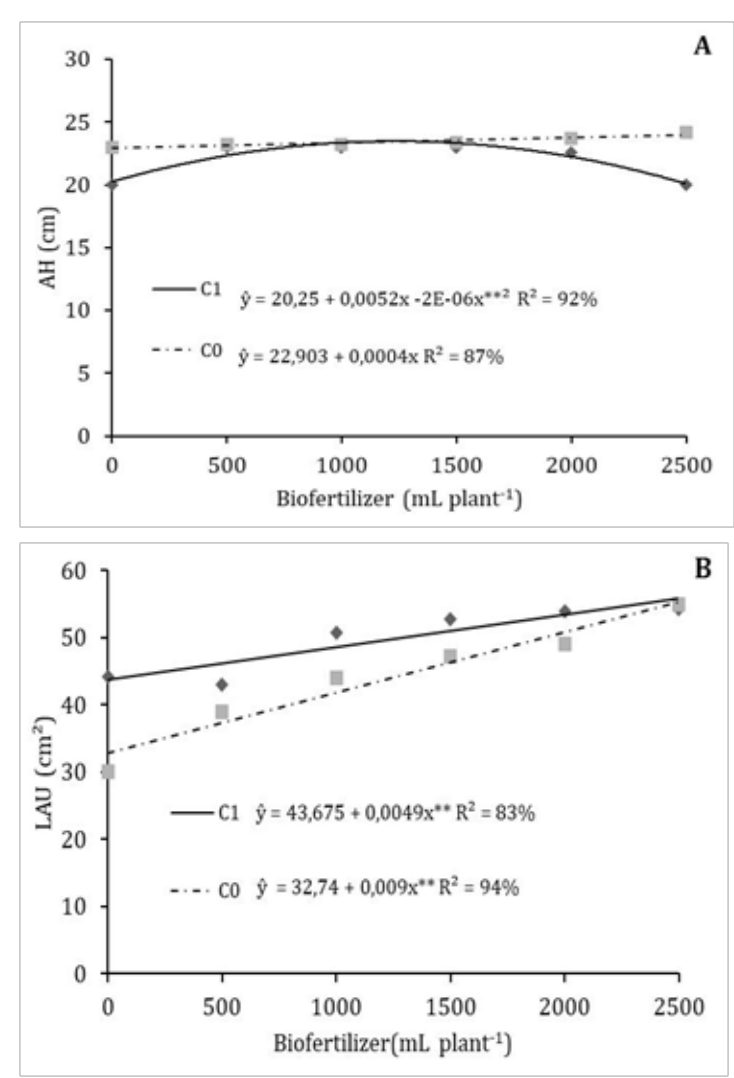

Figure I (AP) Plant height (A) and (AFU) unit leaf area (B) as a function of bovine biofertilizer doses, in the absence $(\mathrm{CO})$ and presence $(\mathrm{Cl})$ of mulch in the dwarf green coconut (Cocos nucifera L.), Belém do Brejo do Cruz, PB, 2014/15.

In the present study, Freire et al. ${ }^{9}$ found a higher average mass of yellow passion fruit in the mulch and biofertilizer interaction with non-saline water, providing a mean mass of $193.7 \mathrm{~g}$, about $38.5 \%$ higher than fruit mass from the control. With the increase of the doses of biofertilizer, independent of the coverage, an increase in the unit leaf area was observed, in which the dose $2500 \mathrm{~mL} / \mathrm{plant}$ stimulated larger leaf area $\left(55.92\right.$ and $\left.55.24 \mathrm{~cm}^{2}\right)$, respectively, with an increase of 21.89 (C0) and $40.7 \%$ ( $\mathrm{C} 1)$ compared to the $0 \mathrm{~mL} /$ plant dose (Figure 1B). Probably due to the supply of macro and micronutrients, the application of the patches and their release during the crop cycle..$^{20}$ Dantas et al. ${ }^{18}$ corroborated with the results of the research, found in acerola plants, as the biofertilizer content in the substrate increased, the height of the plant presented a larger increase in the highest dose. Also Constantino et al. ${ }^{21}$ verified higher height in papaya seedlings with biofertilizer application. Different results were found by Sediyama et al. ${ }^{20}$ which height of Blonde pepper was not influenced by the growing postures of biofertilizer. In the evaluation of leaf area of the plant showed a quadratic behavior in the doses of biofertilizer in the presence and absence of coverage (Figure 2A). In that the dose estimated by derivation $1000 \mathrm{~mL} /$ plant for both coverages, stimulated a greater increase of 364.49 and $358.8\left(\mathrm{~cm}^{2}\right)$. There was an increase of 18.5 and $12.54 \%$, respectively, compared to the dose of 2500 , with savings of 1500 mLplant $^{-1}$ in each coverage.

The presence of a higher biofertilizer content has contributed to the increase of the population of competing microorganisms by nutrients such as nitrogen and potassium. ${ }^{22}$ As a result, there was a decrease in the leaf area of the plant. The same authors verified, when there was an increase of the doses of biofertilizer in the presence of salt water, it fell to the leaf area in corn plants. Gomes et al..$^{23}$ observed that the increase of the doses of biofertilizer promoted higher productivity in maxixe plants in the cultivar Liso Gibão until the optimum point, from the same there was decrease. Also found by Martins et al. ${ }^{24}$ when their treatments were constituted by biofertilizer, cattle manure and inoculant obtained a $60 \%$ increase of common bean yield when compared to the control. Leaf area index (LAI) did not observe a significant effect for treatments and interaction of factors. However, in the regression, the effect was verified at $5 \%$, with a quadratic behavior as the doses of biofertilizer increase (Figure 2B). The highest increase (LAI) was found at an estimated dose of $1000 \mathrm{~mL} /$ plant of $0.88 \mathrm{~m}^{2}$, and an increase of $5.68 \%$ of dose 0 (zero) $\mathrm{mL} /$ plant. According to Santos et al..$^{25}$ the bovine biofertilizer releases humic substances in the soil, in which it improves soil structure and increases microbial populations, increasing the solubility and availability of some nutrients, such as P.
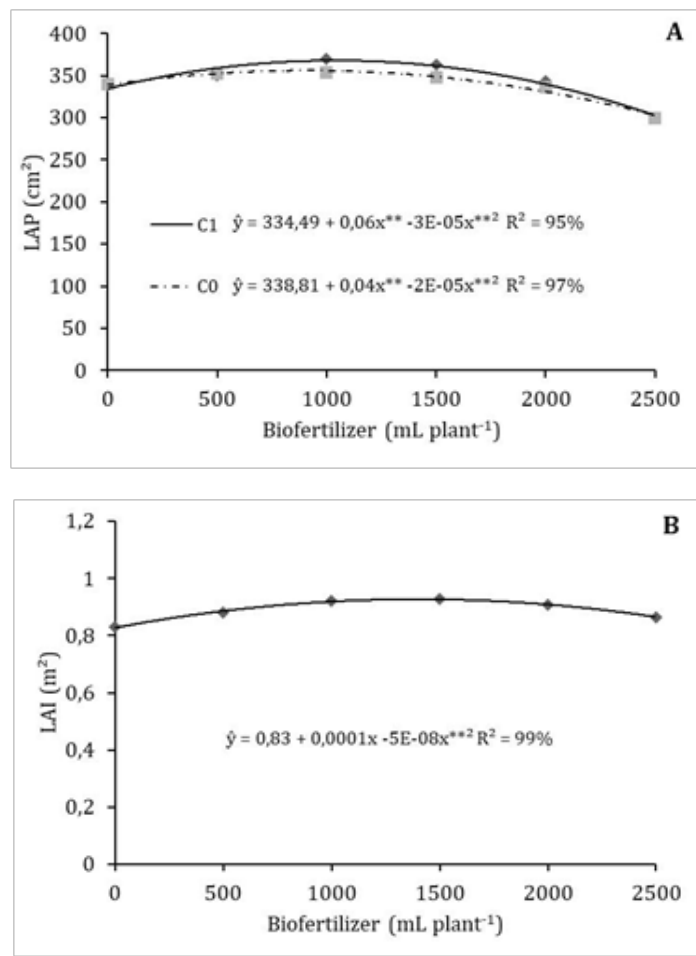

Figure 2 Leaf area of the plant $(A)$ as a function of the doses of bovine biofertilizer, in the absence $(\mathrm{CO})$ and presence $(\mathrm{CI})$ of mulch and leaf area index $(B)$ on the biofertilizer doses in the culture of the green dwarf coconut (Cocos nucifera L.), Belém do Brejo do Cruz, 20I4/I5.

The same authors point out that the positive influence of applied organic sources via soil on productive aspects of agricultural crops is related to the nutritional effect and consequently to the physiological indices. Silva et al. (2016) observed that the fig tree (Ficus carica L.) responds positively to increasing doses of bovine biofertilizer when applied via soil in fertirrigation, in number of fruits per plant. Ferreira et al ${ }^{26}$ found different results in Paraguaçu castor bean due to the levels of bovine biofertilizer, in the leaf area of the plant. The mulch promoted a greater number of leaflets per leaf, probably the cover drowned the weeds at the beginning of the crop without direct or indirect competition, besides minimizing water loss through evaporation and soil temperature. Or the cover decomposed by the microorganisms has released $\mathrm{N}$ to the plants (Figure 3A) Results also verified by Lima et al. ${ }^{27}$ where the yield of common bean (princess) was higher when submitted to soil cover. Galvão et al. ${ }^{28}$ verified that the dry mass of the aerial part increased when the no-till was done with the mulch of the weeds. 
In no-tillage, there is an increase in $\mathrm{Ca}+2, \mathrm{~K}+, \mathrm{P}$, in the sum of bases, total organic carbon, reduction of soil acidity components and increase in the cation exchange capacity up to a depth of $0.20 \mathrm{~m}$ (Campbell et al., 2011). The number of leaflets per plant (Figure 3B) decreased with increasing doses of biofertilizer, with a decrease of $2.99 \%$ in the dose of $2500 \mathrm{~mL} / \mathrm{plant}$ of the control. A different result was found by Oliveira et al. ${ }^{6}$ when the biofertilizer combined with increasing doses of bovine manure increased leaf $\mathrm{K}$ content in maxixe plants. The same authors concluded that maxixe responds significantly with the use of bovine manure associated with biofertilizer. According to Sá et al. ${ }^{29}$ the bovine biofertilizer promoted reduction of soil salinity, providing better growth and dry matter accumulation of the sunflower plants.
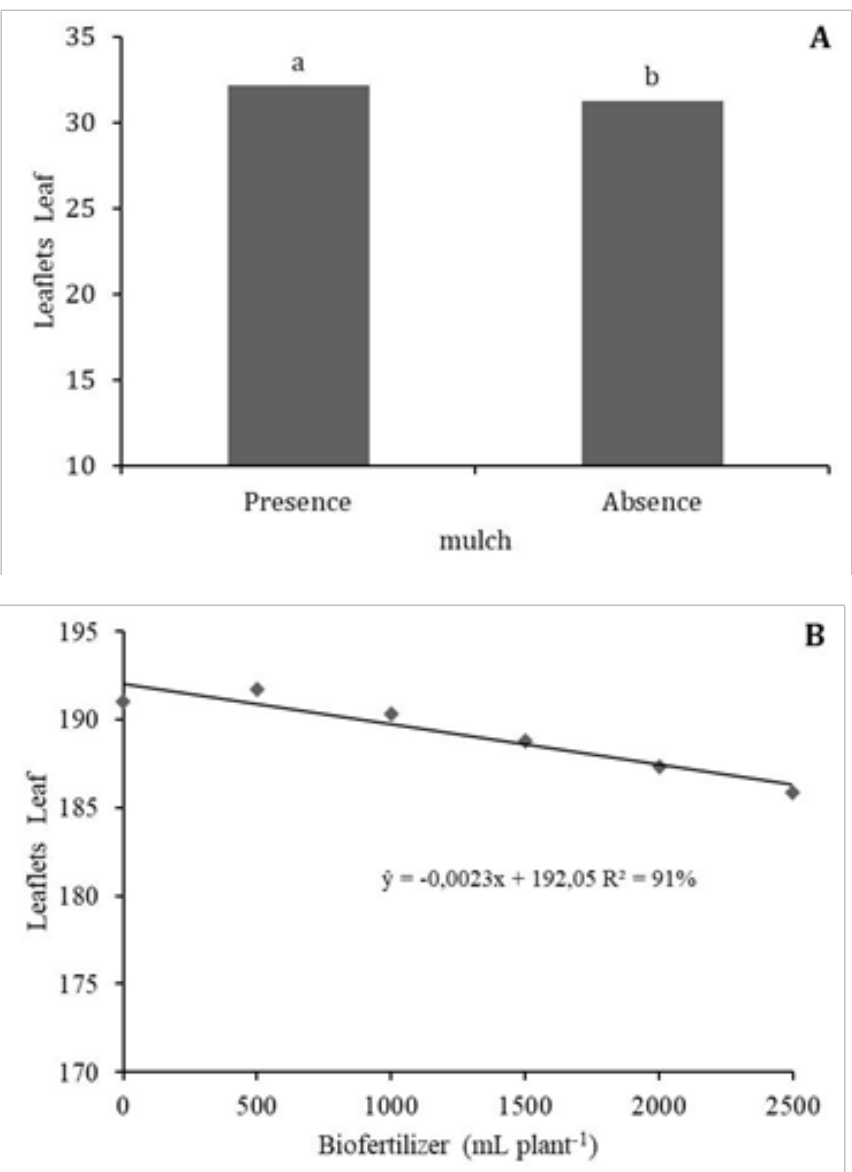

Figure 3 Number of leaflets per leaf (A), as a function of mulch and number of leaflets per plant $(B)$ submitted to doses of biofertilizer on green dwarf coconut (Cocos nucifera L.), Belém do Brejo do Cruz, PB, 20I4/I5.

\section{Conclusion}

The biofertilizer and mulch can be an alternative to family farming, in the cultivation of the green dwarf coconut (Cocos nucifera L.).

\section{Acknowledgements}

None.

\section{Conflict of interest}

The author declares there is no conflict of interest.

\section{References}

1. Ribeiro G, Monnerat PH, Campanharo M, et al. Potassium fertilization applied on leaf axillary and soil in green dwarf coconut. Journal of Ceres. 2016;63(1):68-75.

2. Matias SSR, Aquino B, Freitas JAD, et al. Leaf analysis of dwarf coconut in two different times in relation to nitrogen and potassium doses. Revista Agronomica. 2006;37(3):264-269.

3. Tracth R, Bettiol W. Effect of biofertilizers on mycelial growth and spore germination of some phytopathogenic fungi. Pesquisa Agropecuária Brasileira, Brasília. 1997;32:1131-1139.

4. Resende GM, Yuri JE, Costa ND, et al. Performance of carrot cultivars under organic growth system under high temperature conditions. Horticultura Brasileira. 2016;34(1)121-125.

5. Oliveira AP, Silva OPR, Bandeira NVS, et al. Maxixe yield in sandy soil as a function of bovine manure and biofertilizer doses. Brazilian Journal of Agricultural Environmental Engineering. 2014;18(11):1130-1135.

6. Oliveira JR, Gomes RLF, Araújo ASF, et al. Nutritional status and pepper production with the use of liquid biofertilizers. Brazilian Journal of Agricultural Environmental Engineering. 2014;18(12):1241-1246.

7. Santos TAPGS, Va Viana VA, Sousa GG, et al. Productivity and fruit quality of melon according to types and doses of biofertilizers. Horticultura Brasileira. 2014;32(4)409-416.

8. Mesquita FO, Cavalcante LF, Pereira WE, et al. Production of yellow passion fruit seedlings submitted to salinity in soil with bovine biofertilizer. Cienciadel Suelo. 2012;30(1):31-41.

9. Freire JL, Cavalcante LF, Rebequi AM, et al. Qualitative attributes of yellow passion fruit produced with saline water, biofertilizer and mulch in the soil. Brazilian Journal of Agricultural Sciences. 2010;5(1):102-110.

10. Campos AC, Medeiros AS, Gomes AT, et al. Evaluation of the vegetative growth of dwarf coconut trees submitted to the application of liquid biofertilizers. Green Journal of Sustainable Agroecology. 2014;9(1):168-175.

11. Souza ER, Montenegro AAA, Montenegro SMG, et al. Temporal stability of soil moisture in irrigated carrot crops in Northeast Brazil. Agricultural Water Management. 2011;99(1):26-32.

12. Ferreira ICPV, Araujo AV, Nascimento AL, et al. Dead cover and organic fertilization in lettuce production and weed suppression. Journal of Ceres. 2013;60(4):582-588.

13. Santos ACV. Biofertilizer liquid: the defensive of nature. 2ed. See Niterói: EMATER - Rio, 1992. (Agropecuária Fluminense, 8).

14. Watson DJ. The physiological basis of variation in yield. Advances in Agronomy. 1952;4:101-144.

15. Ferreira DF. SISVAR - System of analysis of variance. Version 5.3. Lavras-MG: UFLA; 2010.

16. Damatto Júnior ER, Nomura ES, Fuzitani EJ, et al. Experiments with the use of organic fertilization in banana cultivation. In: Godoy et al. edtors. Topics on nutrition and fertilization of banana crops. Botucatu: FEPAF/ UNESP; 2009. 94-120 p.

17. Malavolta E, Vitti GC, Oliveira SA. Evaluation of the nutritional status of plants: principles and applications. Associação Brasileira para Pesquisa da Potasse e do Fosfato, Brazil. 1997. 201 p.

18. Dantas KA, Figueiredo TC, Mesquita EF, et al. Substrates and doses of bovine biofertilizer in the production of saplings. Green Journal of Sustainable Agroecology. 2014;9(1):157-162. 
19. Alves FIS, Medeiros AS, Campos AC, et al. Production of banana nanicão (musa sp.) According to types and doses of fertilizers. Green Journal of Sustainable Agroecology. 2013;8(5): 58-68.

20. Sediyama MAN, Santos MR, Vidigal SM, et al. Nutrition and productivity of colored pepper plants, fertilized with pig biofertilizer. Brazilian Journal of Agricultural and Engineering Environmental. 2014;18(6)588-594.

21. Constantino M, Gómes-Álvarez G, Álvarez-Solís. Effect of labiofertilization and bioregulators on germination and growth of Caricapapaya L. Revista Colombiana de Biotecnología. 2010;12(2):103-115.

22. Sousa GG, Marinho AB, Albuquerque AHP, et al. Initial corn growth under different concentrations of bovine biofertilizer irrigated with salt water. Journal of Agronomy. 2012;43(2)237-245.

23. Gomes LP, Oliveira FA, Bezerra FMS, et al. Productivity of cultivars of maxixer as a function of doses of biofertilizer. Revista AgroAmbiente, Roraima. 2015;9(3):275-283.

24. Martins JDL, Moura MF, Oliveira JPF, et al. Bovine, biofertilizer, inoculant and combinations in the productive performance of common bean. Revista AgroAmbiente. 2015;9(40):369-376.
25. Santos JGR, Andrade R, Galdino P, et al. Quality of Nanicão due to production of biofertilizers. Revista Brasileira de Engenharia Agrícola Ambiental. 2014;18(4)387-393.

26. Ferreira NM, Mesquita EF, SÁ FVS Bertino, et al. Growth and production of BRS Paraguaçu castor bean under irrigation, soil cover and organic fertilization. Revista Brasileira de Engenharia Agrícola Ambiental. 2015;19(9):857-864.

27. Lima RAS, Silva S, Santos MAL, et al. Efficiency in water use by bean cultivars (Phaseolus vulgaris L.) with and without mulching. ACSA Scientific Agropecuária in the Semi-Arid. 2013;9(3):18-25.

28. Galvo RO, Araújo Neto SE, Ferreira RLF. Organic direct lettuce planting on live and dead cover and fertilized with compost. ACSA-Scientific Agropecuária in the Semi-Arid. 2013;9(3):75-80.

29. Sa FVS, Bertino AMP, Mesquita EF, et al. Influence of gypsum and biofertilizer on the chemical properties of a saline-sodium soil and the initial growth of the sunflower. However. 2015;20(1):46-59. 